\title{
Cahsless Society on GoPay: An Islamic Economic Perspective
}

\author{
Dita Anis Zafani ${ }^{1}$ and Moh. Musfiq Arifqi ${ }^{2}$ \\ ${ }^{1}$ Universitas Islam Negeri Sunan Ampel \\ ${ }^{2}$ STAIM Terate Sumenep \\ email: dita.zafani@gmail.com,musfiqarifqi18@gmail.com
}

\begin{abstract}
Technological developments have led to massive Cashless Society activities among the public, especially in GoPay transactions. Indonesian people, who are predominantly Muslim, have started to shift their payment system from cash to cashless transactions. Therefore, the study of Islamic economics is important to see this phenomenon. The qualitative-descriptive research methodology was used by researchers to examine this research. A standard general procedure of library research is done to obtain data from several scientific papers in the form of books, magazines, journals, articles, documentation and other relevant media. The results of this study state that the Cashless Society's activities through GoPay transactions can be said to be in accordance with the principles of Islamic economics. This can be proven in the transaction that there is no party that loses money between the customer and the service provider, and there is no interest in the transaction. In addition, the Cashles Society can provide convenience in transactions between economic actors, as well as a more reliable guarantee of security.
\end{abstract}

Keywords: Cashless Society; GoPay; Indonesia; Islamic Economics.

\section{INTRODUCTION}

Economic activity in general has continued to experience development, back to the time of the Prophet Muhammad continued to the period of Khulafaurrasyidin, followed by classical economist thought and even contemporary economists 
figure. This development continues to occur until now where peopleenter the era of industry 4.0 due to the increase in science, technology, and the diverse needs and desires of humans. This requires economists to continue to compete no longer on a local or national scale but have increased on a global or international scale.

Indonesia is one of the countries which also has a very fast economic development. This development is partly due to the increasingly massive development of technology. Indirectly, people are being demanded to continue to develop various innovations to boost the economy. Among the innovations that continue to develop today is the use of digital transaction exchange tools. The transaction scheme has gradually been passed by economists and has been applied by the community, starting from the barter system using a medium of exchange for valuable goods in the form of coins from gold or silver, continued by the use of fiat money as we use today, next to the cashless payments that start to develop, such as GoPay, Ovo, Dana and others.

Digital transactions in Indonesia have experienced significant growth. From 2013 to 2017 it has grown by 169 percent from IDR 49 trillion to IDR 132 trillion. The highest growth was dominated by transactions via mobile applications, which grew by 383 percent since 2013 . In addition to that, transactions for retail through mobile applications grew the highest with a growth of 2,437 percent from IDR 1 trillion in 2013 to IDR 38 trillion in 2017 (BPSI, 2018).

In 2018 The Center Body for Indonesian Statistic reported that the number of electronic transactions reached Rp. 24,82 million transactions with a transaction value of $\mathrm{Rp} .17,21$ trillion and is expected to grow along with the increasing number of internet, mobile and social media users.

This data represents a revolution of people's lifestyle in the era of the digital economy. They have switched to use noncash financial instruments in their daily transactions. This is an opportunity as well as a challenge for the development of the Islamic economic system in Indonesia. So far, Islamic economics is known as one of the economic systems that upholds ethical 
values and is transparent in all its activities. This is a necessity for Islamic economists to be able to provide education about all forms of these changes. By doing so, the current social revolution can be increased to continue to uphold Islamic economic values, as well as provide opportunities to continue the development of Islamic economics among the community amidst this digital era.

In addition, the cashless society revolution in the digital era has become one of the master plans ofIslamic economics in Indonesia for 2019-2024 as a form of strengthening Indonesia's digital economy. This is due to the existence of the largest digital product consumer market in Southeast Asia which is estimated to continue to grow and the increasingly rapid presence of e-commerce, which will also result in an increase in the number of electronic transactions in Indonesia (BPSI, 2018) (BPPN, 2018).

GoPay is present as a new payment system in Indonesia where the largest Muslim population reside in this country. This phenomenoninspires the author to conduct an in-depth study on this occurence from Islamic economic perspective. However, to support the Islamic economy ecosystem in Indonesia, the use of Sharia label must be supported with concrete evidences in accordance with the rules of ushul fiqh and fiqh. When such work is done, the presence of a new Islamic payment instrument will truly become the identity of Indonesian people embedded with Islamic spirits.

Academists continue to conduct research on transactions based on Islamic economics in order to contribute ideas and education to society in carrying out economic activities. One of the most recent studies regarding the development of economic transactions was conducted by Indra and Rofiqoh (2019). The results of his research state that payments using the Go-Pay balance on the Go-Jek application can be used by Muslim, provided that Go-Pay must comply with the principles of shari'ah by avoiding ribawi transaction, gharar, maysir, tadlis, risywah, israf and transactions on objects that are haram or immoral. In addition, the existence of Go-Pay is included in the protection of assets (hifdz al mâl) and has a positive impact on the movement of the Indonesian economy. 
Furthermore, research conducted by Muamar and Alparisi (2017) states that electronic money (e-money) emerges as a new innovation that answers people's needs for micro payment instrument that can make the payment process faster, more efficient and safer. The results of this study imply that electronic money is very helpful for the public in making transactions. However, in addition, based on research conducted by Hiyanti et al., (2020), it is stated that there are opportunities and challenges for sharia fintech in Indonesia which consist of: regulation, human resources, and control of technology from the community. This challenge is one of the responsibilities of Muslim economists or Muslim communities to continue to preserve Islamic economic values in all their economic activities.

Besides, Go-Pay as digital wallet also fulfilled four Islamic business ethics that has been explained by Zulni and Achiria (2020). The ethics consist of 4 axioms which the author concludes as follows: unity, fairness or justice, free will, and responsible. Unity is when the services provided by Digital Wallet are the in same form despite of customers's background. As for the fairness, Digital Wallet is not only meant for business transactions, but is also expected to become a wallet as a place for social funds so that the social transaction can be easily conducted trough Digital Wallet. Next is the free will which means Digital Wallet is expected to work together with various halal merchants to be able to facilitate users in making transactions so that Muslim users can feel safe when he transacts purchases with halal merchants to get the pleasure of Allah. Last is the responsibility where Digital Wallet as a financial digitalization is expected to be able to secure the nominal or balance of users who use their services such as the history of transactions using the Digital Wallet and also the security of user data.

Furtehrmore, Garcia-Swartz, Hahn and Layne-Farrar (2006) in examining the empirical evidence of the move toward cashless society using cost-benefit framework found interesting result. The research concludes that when all key parties to a transaction are considered and benefits are added, cash and checks are more costly than many earlier studies suggest. In general,the shift toward a cashless society appears to be a beneficial one. 
Financial ability, ease and security have a positive and significant impact on financial technology (Go-Pay) as documented in a research by Kamil (2020). Financial ability will make it easier to charge the electronic money (Gopay), the more ease that is offered, the more interested in using, and also the greater security is offered, the greater a person's interest in using to be cashless society.

Based on some of these previous studies, the more sophisticated technology can affect the form of the economic payment system which will have an impact on people's lives today. In modern times, people prefer to use an electronic payment system instead of using a cash system transaction. This is due to the ease with which electronic payments are offered. Therefore, the revolution in the cashless payment system needs to be continuously studied, in order to provide education and knowledge to the people of Indonesia in their daily transactions.

This study wants to try to examine it from a different point of view based on previous research. This research focuses more on the study of the Islamic economic view of the existence of GoPay non-cash transactions that are increasingly developing in Indonesia and supports the realization of the Cashless Society. The researcher wants to see the position of the Islamic economy when faced with the form of this transaction.

\section{LITERATURE REVIEW \\ Cashless Society}

The term cashless society is a new term that has emerged along with technological developments. This technological development requires economists to be more creative and innovative. Bank Indonesia is making one of the efforts to support improvements in the efficiency and business climate, namely the National Cashless Movement (NCM) on August 14, 2014. NCM is intended to increase public awareness of the use of noncash instruments so that a proper cashless society who utilizes more cashless instruments can be gradually formed, especially in conducting transactions for their economic activities. Cashless Society is inseparable from the development of information 
technology which encourages more easy, innovative, efficient and safe to use means of payment (Bank Indonesia, 2014).

Cashless Society is where people or communities no longer see money in its physical form such as pieces of paper or metal coins. It is rather replaced by electronic money as the medium of transactions. The emergence of the Cashless Society is also based on the fact that physical use of cash in transactions requires a large amount of money, especially in the issuance of physical money, circulation and distribution, maintenance and replacement of damaged/obsolete money. Apart from the reasons above, there are several other factors that trigger the idea of the Cashless Society which includes (Rif'ah, 2019):

1. Awareness of several potential fraud and crimes caused by physical money, such as the circulation of counterfeit money.

2. Public awareness that does not depend onn physical money will in fact facilitate the government in coordinating and supervising any financial and trade transactions through access to electronic reports that are difficult to manipulate.

3. Transactions without involving physical transfer of money will also reduce the possibility of corruption and collusion against the transacting parties, especially those related to public services.

4. Speed up the economic transactions.

Electronic money as an innovative and practical means of payment is expected to help in smoothing payments for mass, fast, and micro economic activities, so that its development can further be used in any other transactions such as in highway payment, railways, public transports, minimarkets, food courts and even the parking services.Electronic money in Indonesia is still not massively used. According to Bank Indonesia, As of January 2020, the number of electronic moneysin circulation was still $313,785,298$ billion Rupiah. This is totally different from developed countries such as China which had already gone cashless (Kasali, 2018). Bank Indonesia showed special attention to electronic money by presenting the Quick Response Indonesia Standard (QRIS) to make it easier for people to transact via digital. 
Its legitmation comes from Regulation of the Board of Governors Number 21/18 / Padg / 2019 concerning the Implementation of the National Standard Quick Response Code for Payment. Quick Response Indonesia Standard is a QR Code Payment Standard set by Bank Indonesia to be used in facilitating payment transactions in Indonesia using only one QR Code. As a result, one QR Code can be used for all digital payment platforms. GoPay has become a registered platform in it. Thus, as we can see, in order to make Indonesia a cashless society, support, competence of its human resource, and optimistic mindset from both the government and Indonesian people is absolutely needed.

\section{Medium of Exchange in Islam}

The medium of exchange is one of the most important things to fulfill life. In Islamic Economics, money is often associated with the terms Dinar and Dirham. Muslims use the word dinar to denote currency made of gold, while the word dirham to denote a medium of exchange made of silver. They also used the word wariq to denote silver dirhams and the word 'ain to denote gold dinar. Meanwhile, the word fulus (copper money) is an additional medium of exchange used to buy cheap goods (Hasan, 2005). In addition, some Muslim scientists such as Abu Ubaid, Imam Ghazali, Ibn Rushd and Ibn Qayyim identified money as a measure of price.

Abu Ubaid stated that Dirham and Dinar are the value of the price of something while in the opposite everything else cannot stand as valuation of those two (Abu Ubaid, 1988). Imam Ghazali emphasized that Allah created the dinar and dirham as an intermediary judge between all assets so that they could be measured by both. It is said "this camel equals 100 dinars, this is the size of this za'faran oil equals to 100". Both are approximately equal to one size, so they both have the same value. Ibn Rushd stated that when it is difficult for someone to find the equivalent value between different items, use dinars and dirhams to measure them. If someone sells a horse with clothes, the value of the horse's price for several horses is the value of the clothes for several clothes, so if the horse is worth 50 , of course the clothes 
must also be worth 50. Ibn Qayyim said that dinar and dirham are the price values of commodity goods. Thus the price value must be a known measurement, so it must be specific and accurate with no upward nor downward fluctuation. This is because if the unit of price value can go up and down like a commodity itself, of course it will no longer have a unit of measure that can be confirmed to measure the value of the commodity (A. A. Karim, 2015).

Money is also a legitimate medium of transaction when the states declare it. Umar bin Khattab when he was Caliph once aspired to issue a policy of making dirhams from camel skin. This history isquoted in Tafsir al-Shan'any which read "I wanted to make dirham money from camel skin". Then he was told" then, there will be no more camels."Then Umar gave up his mind (AlHaritsi, 2006)

Here there is an affirmation of the tradition ('urf) in accepting money. Money is not limited to the two existing currencies (dinar and dirham). Money is also a storage medium for value, because people who get money sometimes do not spend it all at one time, but they set aside a portion to buy goods or services they need at the time they want, or they save it for unexpected things such as illness. suddenly or face unexpected losses (Hasan, 2005). From the description above, money can be distinguished in three ways: a. The definition of money in terms of economic functions as a standard measure of value, medium of exchange, and pending means of payment.

b. By looking at its characteristics, money is everything that is widely accepted by each individual

c. In terms of laws and regulations, as anything that has legal force in settling liability obligations.

Ibn Taymiyyah expressed his opinion in Majmu 'al-Fatawa that there is no natural or shar'i limitation regarding the use of dinars and dirhams rathere the reference is to custom (' adah) and agreement. This is because basically the purpose of people using dinars and dirhams is not related with the substance, but as a standard for the object of the transaction they do (Ibnu Taimiyah, 2002). Physical dinars and dirhams are only used as 
a means to make transactions. Therefore, the dinar and dirham (only) functioned as a tsaman (price, standard of value). Unlike other assets (goods), goods are intended to be used physically. Therefore, goods must be measured in natural or syar'i terms (measurements). Only means that are physical or in form are not the end may be used to achieve the goal, regardless of form.

\section{Islamic Economics}

Islamic economics is an alternative economic system that is able to offer a more ethical economic management concept. This Islamic economic system departs from the awareness of the importance of an ethical economy, while other economic systems, both capitalism and socialism, depart from interests. Capitalism departs from individual interests (selfishness) and socialism departs from collective interests (collectivism). With such ethics based economics, religion does not become a tool for an interest. The task of the people is to think that their religion demands an ethical economy but is still responsive to real interests (Kuntowijoyo, 1997).

In the Islamic economic system all forms of activity are always associated with worship. This worship then affects all forms of production, consumption, distribution and other economic interactions. Specifically, there are at least three main motives in Islamic economic behavior, namely mashlahah (public interest), needs and obligations (Khan, 1997). Meanwhile, according to Al-Shadr (1994), Islamic economics consists of three basic components that differentiate it from other economic system theories, namely: a) the principle of multi-faceted ownership, b) the principle of economic freedom within set limits, c) the principle of social justice. Metwally (1995) explains in detail some of the principles in Islamic economics that make it different from other economic systems as described below:

1. In Islamic economics, various types of resources are viewed as gifts or entrusted by God to humans. Humans must make use of them as efficiently and optimally as possible in production to meet the welfare together in the world, namely for themselves and others, and most importantly these 
activities will be accounted for in the hereafter. This concept has important implications regarding ownership of assets or means of production.

2. Islam recognizes private ownership within certain limits, including ownership of means of production or factors of production. However, individual property rights are not absolute and conditional. Individual ownership in Islam is limited by the interests of society. If the country wants a certain asset, then the owner of the asset must release it. This is one of the principles contained in the shari'ah which states that individual interests must be number two compared to the interests of society as a whole.

3. The main driving force of Islamic economics is cooperation, which is very different from the free market system in achieving a level of balance in various fields. Cooperation is an Islamic spirit to satisfy buyers and sellers of goods, services or production factors.

4. The role of ownership of wealth / assets in an Islamic economy is different from other economies. Pure satisfaction obtained from the control of private wealth in other economic systems will produce human beings who are selfish. Whereas in Islam, personal wealth must play a role as productive capital which will increase the amount of national production and improve the welfare of society. This concept of ownership is the opposite of the capitalist system. Therefore, the Islamic economic system rejects the accumulation of wealth controlled by several people.

5. In a free market economy, industrial ownership is dominated by monopoly and oligopoly, and these industries are very important to the public. Islam guarantees the ownership of society and its planned use for the benefit of many people.

6. A Muslim must believe that all his activities in this world will be accounted for later in the hereafter. Therefore, Islam denounces excessive profit, dishonest trade, unfair treatment, all forms discrimination and oppression. 


\section{METHODS}

The method used in this research is descriptive qualitative. Qualitative method is research that aims for limited objects while under this circumstance it can come up with an in-depth data analysis (Bungin, 2001). Meanwhile, descriptive research, according to Sugiyono Sugiyono (2014), is a systematic description of the theory and research results relevant to the variables studied.The type of research used is library research, namely the technique of collecting data through libraries, in the form of books, magazines, internet media and some relevant references. After the data was collected, the researcher analyzed it qualitatively. Qualitative data analysis can be carried out starting from organizing the data, sorting it into manageable units, looking for and finding patterns, finding what is important and what is learned and deciding what to tell others (Moeloeng, 1989).The steps taken include data reduction, data display, data verification and conclusions.

\section{RESULTS AND DISCUSSION GoPay Transaction Services}

The use of electronic money as a medium of transaction in Indonesia is officially legalized by Bank Indonesia under Bank Indonesia Regulation Number 20/6/PBI/2018 on Electronic Money. It is stipulated there that Electronic Money is a legal payment instrument in accordance with prevailing elements. The regulation is reinforced by the Fatwa of the National Sharia Council of the Indonesian Ulama Council No: 116/DSNMUI/2018 onIslamic Electronic Money, that all electronic money administrators consist of:

1. Issuers, both bank and non-bank

2. Electronic money holders, who are the users of electronic money

3. Principals, system managers among members

4. Acquirers, non-bank institutions cooperating with traders so that they are able to transact from electronic money

5. Merchants, sellers of goods / services who accept electronic money payment transactions 
6. Clearing operators, banks or non-banks that calculate the rights and obligations of each issuer

7. The final settlement organizer, is responsible for the final settlement of financial rights and obligations

8. A third party digital financial service agency in collaboration with the issuer.

GoPay is an electronic money and digital wallet founded by PT. DompetAnakBangsa which is legalized and supervised by Bank Indonesia. GoPay has a function as physical money and can be used as a valid payment instrument with the same value as the first cash deposit in the GoPay account (Danuarta \& Darma, 2019). GoPay is an account that is given to GoPay users after registering. GoPay is a payment transaction media that connects consumers and businesses with several services used (Ferdiana \& Darma, 2019). Here are some terms contained in GoPay transactions, namely:

1. Top-Up. Top-up is a service to top up your GoPay account balance that can be done via a gojek driver, transfers via certain banks, or through institutions or platforms specified by PT. Dompet Anak Bangsa as the founder of GoPay.

2. Payment. GoPay can be used to make direct payments on transaction bills where each payment will automatically reduce the balance by the same payment amount.

3. Transfer of Fund. Transfer of funds is a GoPay service for transferring funds to other GoPay accounts which will automatically reduce the transferer's balance and will increase the amount of the balance of the transfer recipient by the same amount.

GoPay is made by the GoJek ride-hailing application founded by NadiemMakarim.GoJek has received funding from several companies, including Google, Tencent Holdings, Temasek Holdings, Astra Interansional and MeitunDianping with a total funding of USD 585 million (BPSI, 2018). GoJek combines several features and services in one application based on needs, namely, 1) daily need, such as GoMassage, GoClean, GoFitness; 
2) food and FMCG, GoFood, GoShop, GoMart, GoMart, GoMed, GoMall; 3) news and entertainment, such as GoTix, GoPlay, GoGames, GoNews; 4) payments, such as GoPulsa, GoPoints, GoNearby, GoBills, GoGive, GoSure; 5) transport and longistic, such as GoRide, GoCar, GoBluebird, GoSend, GoBox.

Costumers prefer to use GoPay in GoJek due to its offered promotions. In addition to that, it is easy to use and speed up the transaction process by eliminating the difficulty of finding change. Besides, GoPay is a safe and trusted platform with a certificate license from Bank Indonesia since October 2017. GoPay transactions have contributed $30 \%$ of the total number of electronic money transactions in Indonesia. In 2017, GoJek was awarded as the most proactive fintech company in supporting the national non-cash movement(Raharja, Muhyi, \& Herawaty, 2020).

\section{GoPay Transactions In Islamic Economics}

The pattern of transaction innovation in accordance with Islamic economics is always based on Al-Quran, Hadith and Ijma'. All forms of business transactions which comply the principles of Islamic economics always pay attention to individual rights that must be protected as well as to uphold a high sense of solidarity with the community (A. Karim, 2013). Basically the contract contained in the GoPay transaction or on other similar Fintech does not contradict Islamic economic principles. This refers to one of the principles of muamalah, namely 'an-taradhin which means mutual approval between the two parties. It is on this basis that the contract or transaction between the two parties becomes valid (Arner, 2014).

However, it is not enough to analyze GoPay transactions based on the rules of an-taradin. This requires a more detailed study if it is related to the existing Islamic economic principles. The basic principle of Islamic economics is based on ethics in all its activities. Here, GoPay transactions have provided ethical code of conduct that consumers should comply with. The code of ethics is none other than to regulate the patterns of services provided to consumers, such as top-ups, payment services and 
others. From an Islamic economic point of view, all forms of services in GoPay can be said to be ethical, because no one is disadvantaged in their activities.

Considering that the GoPay payment system has the same function as cash, Bank Indonesia has set several provisions that must be fulfilled by Banks and Non-Bank Institutions in conducting GoPay transactions. Among the provisions are these three elements:1) In issuing GoPay, it must be based on the value of money that has been previously deposited to the issuer; 2) Value of money is stored electronically in a media server or chip; and 3) The value of electronic money managed by the issuer is not a deposit as referred to in the Law on banking. In addition, Bank Indonesia has also set several regulations that must be fulfilled by all e-money operators including GoPay transactions, such as the obligation to implement risk management, reporting, system security and others.

Furthermore, GoPay transaction service meets several standards in the Islamic economy. Among them, based on its function, GoPay already has a function as a means of exchange in the Islamic economy, namely as a standard measure of value, a medium of exchange and a deferred payment instrument (Karim, 2015). In addition, GoPay is widely accepted by each individual and has been legitimized by law in all its activities.

The suitability of practices between GoPay transactions or electronic money and the function of the Cash Money exchange tool has been confirmed by the Fatwa of the National Sharia Council of the Indonesian Ulama Council No: 117/DSN-MUI/ II/2019concerning Information Technology-Based Financing Services Based on Sharia Principles. Bank Indonesia also regulates electronic money as a legal payment instrument by complying with the following principles (see Regulation 20/6/PBI/2018):

1. Does not pose a systemic risk.

2. Operations are carried out based on sound financial conditions.

3. Strengthening consumer protection.

4. Businesses that are beneficial to the Indonesian economy.

5. Prevention of money laundering and terrorism financing. 
In terms of the contract used in GoPay transaction service, according to the opinion of researchers, GoPay transactions are included in the Wadiah contract. The reason is, because GoPay is a wallet to pay for all transactions made by Go-Jek and merchants who accept transactions via GoPay. The implementation of the QRIS system makes it easier for people to pay from various platforms using just one QR Code whereGoPay is included in it. Customers only deposit their money in GoPay which will later be used in transactions. So that the contract that occurs to the customer and GoPay is wadi'ah. In GoPay there is no addition or interest to the GoPay balance when the customer top-ups. There are several provisions and limitations of the wadi' ah contract that must be fulfilled which are:

1. The nominal amount of electronic money is deposited. This means that holders can make useGoPay at any time.

2. The nominal amount of electronic money deposited may not be used by the recipient of the deposit (issuer), unless with the card holder's permission.

3. The relevant authorities are obliged to limit the issuer in the use of funds deposited by cardholders.

4. The use of funds by the issuer may not conflict with sharia principles and laws and regulations.

Based on some of the Islamic economic principles above, the Cashless Society's activities on GoPay transaction need to be continuously improved. This is one form of support for the ease of electronic transactions in Indonesia, because at this time it is possible that world economic competition has begun to shift to electronic systems. In addition, Indonesia is facing a world trade war that continues to innovate along with technological developments. The Cashless Society not only supports ease of transactions, but also supports the smooth operation of Bank Indonesia's duties in maintaining monetary stability and supports the government's efforts to prevent corruption or money laundering. 


\section{CONCLUSION}

Based on explanations on GoPay transactions and Cashless Society above, the researchers conclude that GoPay transaction practice is in accordance with the rules in Islamic economics. As a result, this study asserts that the Cashless Society's activities through GoPay transactions can be said to be in accordance with the principles of Islamic economics. This can be proven in the transaction that there is no party that loses money between the customer and the service provider, and there is no interest in the transaction.

This GoPay transaction can make transactions easier. There are provisions that must be fulfilled by Banks and Non-Bank Institutions in conducting GoPay transactions. Among them include three elements: 1) In issuing GoPay, it must be based on the value of money that has been previously deposited to the issuer; 2) Value of money is stored electronically on a media server or chip; 3) The value of electronic money managed by the issuer is not a deposit as referred to in the Law on banking.

In terms of the contract used in the GoPay transaction service, the researcher states that GoPay transactions are included in the Wadiah contract. The reason is, because GoPay is a wallet to pay for all transactions made in Go-Jek as well as certain merchants that have accepted digital payments. Customers only deposit their money at GoPay to make transactions on Go-Jek so that the contract that occurs to the customer and GoPay is wadi'ah. In GoPay there is no addition or interest to the GoPay balance when the customer top-ups.

\section{REFERENCES}

Abu Ubaid, A. bin S. (1988). Al-Amwal. Beirut: Tahqiq of Muhammad Khalil Harras. Dar Al-Fikr.

Al-Haritsi, J. bin A. (2006). Fiqih Ekonomi Umar bin Al-Khattab. Jakarta: Pustaka Al-Kautsar.

Al-Shadr, M. B. (1994). Our Economics (2nd ed.). Teheran.

Arner, D. W. (2014). FinTech and RegTech: Opportunities and Challenges. Asian Institute of International Financial Law 
University of Hong Kong.

BPSI. (2018). Badan Pusat Statistik Indonesia.

Bungin, B. (2001). Metodologi Penelitian Sosial: Format Kuantitatif dan Kualitatif. Surabaya: Airlangga University.

Danuarta, G. L. N., \& Darma, G. S. (2019). Determinants of Using Go-Pay and its Impact on Net Benefits. International Journal of Innovative Science and Research Technology, 4(11).

Ferdiana, A. M. K., \& Darma, G. S. (2019). Understanding Fintech Through Go-Pay. International Journal of Innovative Science and Research Technology, 4(2), 257-260.

Garcia-Swartz, D. D., Hahn, R. W., \& Layne-Farrar, A. (2006). The move toward a cashless society: a closer look at payment instrument economics. Review of Network Economics, 5(2).

Hasan, A. (2005). Mata Uang Islami: Telaah Komprehensif Sistem Keuangan Islami. Jakarta: Raja Grafindo.

Hiyanti, H., Nugroho, L., Sukmadilaga, C., \& Fitrijanti, T. (2020). Peluang dan Tantangan Fintech (Financial Technology) Syariah di Indonesia. Jurnal Ilmiah Ekonomi Islam, 5(3), 326-333.

Ibnu Taimiyah, T. (2002). Majmu' Al-Fatawa (Volume 19). Beirut: Kutub, Dar Al.

Indonesia, B. (2014). Gerai Info Bank Indonesia. Bank Indonesia, Edisi 50/2014/tahun 5/NewsLetterIndonesia.

Indra, S., \& Rofiqoh, Z. (2019). Transaksi E-Money Terhadap Layanan Go-Pay Pada Aplikasi Go-Jek Perspektif Ekonomi Syariah,. Jurnal Al-Ahkam, 15(2).

Kamil, I. (2020). Cashless Society: Pengaruh Kemampuan Financial, Kemudahan Dan Keamanan Terhadap Perilaku Sistem Penggunaan Financial Technology. Al-Mal: Jurnal Akuntansi Dan Keuangan Islam, 1(2), 98-114.

Karim, A. (2013). Hukum Bisnis Syariah dalam Al-Quran. Jakarta: AMZAH. 
Karim, A. A. (2015). Ekonomi Makro Islam. Jakarta: Raja Grafindo.

Kasali, R. (2018). Disruption. Mizan.

Khan, M. A. (1997). The Role of Government in the Economy. The American Journal of Islamic Social Sciences, 14(2).

Kuntowijoyo. (1997). Identitas Politik Umat Islam. Bandung: Mizan.

Metwally, M. M. (1995). Teori dan Model Ekonomi Islam. Jakarta: PT. Bangkit Daya Insani.

Moeloeng, L. J. (1989). Metodologi Penelitian Kualitatif. Remaja Rosdakarya.

Muamar, A., \& Alparisi, A. S. (2017). Electronic Money (e-Money) in Maqashid al-Sharia Perspective. Journal of Islamic Economics Lariba, 3(2), 75-84.

Raharja, S. U. J., Muhyi, H. A., \& Herawaty, T. (2020). Payment as an Enabler for Business Opportunities: A Go-Pay Case Study. Review of Integrative Business and Economics Research, 9, 319-329.

Rif'ah, S. (2019). Fenomena Cashless Society di Era Milenial dalam Perspektif Islam. Al-Musthofa: Journal of Sharia Economics, 2(1).

Sugiyono. (2014). Metode Penelitian Pendidikan Pendekatan Kuantitatif, Kualitatif, dan R\&D. Bandung: Alfabeta.

Zulni, D. A., \& Achiria, S. (2020). Implementation of Islamic Business Ethics in Digital Wallet: Literature Review Approach. EkBis: Jurnal Ekonomi Dan Bisnis, 3(1), 232241. 